
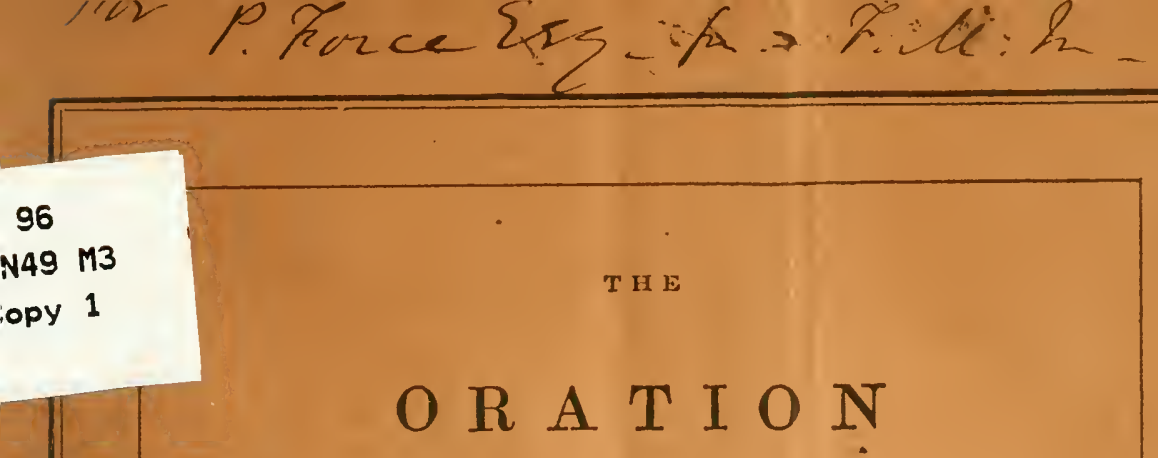

BEFORE THE

\title{
AMERICAN INSTITUTE,
}

BY

P R O F. C. M A S O N.

SECOND EDITION.

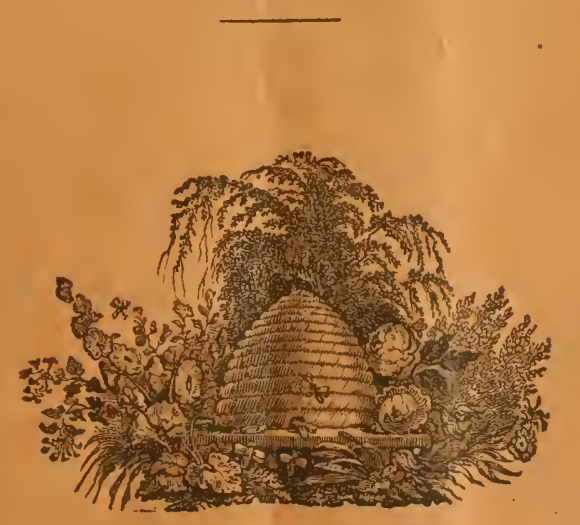

NEW.YORK:

D. APPLETON \& CO., 200 BROADWAY. 1840 . 

THE

\section{O R A T I O N}

ON THE

THIRTEENTH ANNIVERSARY

OF TH E

\section{A M E R I C A I N S T I T U T E,}

DELIVERED BY

$$
\text { C Y R U S M A S O N, }
$$

$\Delta \mathbf{T}$

THE BROADWAY TABERNACLE,

October $15 \mathrm{hh}, 1840$.

SECOND EDITION.

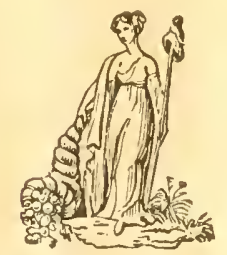

NEW-YORK:

D. APPLETON \& CO., 200 BROADWAY. 1840. 

Professor C. Mason,

Dear Sir :

The Managers of the 13th Annual Fair feel that you have conferred great honour on the American Institute by your very pertinent and able Oration, delivered at the Tabernacle, last evening, and they respectfully request a copy for publication.

Your obedient servant,

T. B. WAKEMAN,

Chairman.

University, October 16th, 1840.

T. B. Wakeman; Esq.

Chairman of Managers of the 13th Annual Fair of the American Institute,

Dear Sir :

Your note, requesting a copy of the Oration delivered by me last evening, is received. I shall defer to the judgement of the Managers, and comply with their request. But I am well aware, that the kindness of a popular assembly, on a public occasion, may have deceived you as to the valuc of a production, which was prepared without leisure, and adapted to the audience and the occasion rather than to the press.

With great respect for the Managers,

I am very truly yours,

C. MASON. 

Mr. President,

and Gentlemen of the Institute:

Turs is the appropriate festival of the working-men of our country. The fruits of genius and industry are brought up in perfection and abundance from the field, the garden, and the work-shop. Your Fair is a national school for the mutual instruction of the ingenious and laborious classes, the true conservators of society. Each labourer comes to submit his work for the common welfare, and to profit by observing the productions of others. And, while each is seeking the advancement of his own art, all are contributing to the common fund of human happiness.

At your call, I come, with alacrity, to offer my appropriate contribution to the service in which you are engaged. I claim here a place and a strict relation for that class of men, who labour in the field of science and letters, and devote their days to the work of public instruction. I deprecate, as unfounded and injurious, the opinion, that the most mature education given in our college halls is an unsuitable preparation for the pursuits of agriculture, commerce, or mechanics. And if, in former days, the notion was cherished in collegiate life, that labour is disreputable to the learned, I here offer the pledge of my associates, that no such heresy is propagated by us: and our pupils, in the counting-houses, offices, and work-shops of the city, are our witnesses. I therefore feel myself at home in this place, on this occasion. 
To you, gentlemen of the Institute, I offer congratulations, rather than praise. If your talents and your position in society have made you the founders and supporters of this institution, I am sure your modesty will prefer to join in the common sentiments of exultation and gratitude, which inspire the prosperous multitude of eitizens, who rejoice together in the results of their and your labours. And if I should attempt the indelicate task of praising you to your faces, I should but faintly and imperfectly echo the voice, which your works have long proclaimed through the length and breadth of the land.

When the kings and feudal lords of other lands find it politic to come forth and speak of the interests of their subjects, they tell wliat they are doing or devising for the prosperity of their people; but, it is your felicity, fellow citizens, to consider and observe what the people are doing for themselves. In the exhibition, which is now closing, we have seen what the people are doing for themselves. And, in an enlightened view of the circumstances, in which the people of this country are doing for themselves, it is manifest, that nothing but treachery to their own dearest rights and highest interests can retard their onward and upward progress to the glory and happiness cherished in the hopes of their patriot fathers.

On a great public occasion, it is fit, that we remind ourselves of those adrantages, which are rather providential than of our orrn procuring; those, which are public, rather than private; those which grew out of our ancestry, our institutions, our climate, and our relations to the older nations of the earth. For, in the eager pursuit of private and personal objects, we are liable to overlook and disregard our public benefits. In long continued peace, patriotism is liable to sink down 
into the selfishness and bigotry of party politics ; liberty is liable to be undervalued and bartered for local interest and corporate power or wealth; and gratitude to a beneficent Providence is liable to be displaced by a vain and misleading self-sufficiency. Could patriotism be kept pure and glowing in the public mind without being rekindled on the battle-field, then would our institutions be perpetual ; for true patriotism is next of kin to national piety; and both are guardians of civil liberty.

To a large extent, individuals and communities are made by the circumstances in which they are placed. Napoleon was ruined by supposing himself an exception to this rule. Intoxicated with the vanity of success, he imagined himself the heir of a peculiar destiny, and the privileged framer of his own fortunes. Had he been duly observant of the natural tide in the affairs of men, lie might have closed his life among the splendours of the French Empire, instead of lingering out his days in dreary and hateful exile. When the first lawyer at the English bar was asked what was the highest prerequisite to legal eminence, he replied, "a shilling to begin with." The life of Franklin is illustrated by the same remark; and so is the history of the New-England race. The American character is eminently the result of the circumstances in which the people of the United States have been placed.

First of all, we are indebted to our AncesTRY.

We are descended from the Anglo-Saxons and the Normans; the most free, constant, and enterprising race of men on the face of the eartl.. We inherit their sobriety, their patience, and their indomitable love of home, of country, and of freedom. Our relation to such 
fathers, has been one cause of that prosperity which has ever distinguished these states from all the colonies around us. It was the very spirit of our ancestors within us, which impelled us to set up for ourselves when we came of age. 'The dread of being shamed by such ancestors, has kept us oll our good behaviour ; now they begin to be proud of us, as we shall never cease to be proud of them. A dignified ancestry is the inleritance of many following generations. Let us never disown or dishonour that inheritance of English sobriety and good sense, which is one pledge of our success in the experiment we are making of enlarged civil liberty.

\section{We are also indebted to our Chunte.}

Our latitude determines the temperature of our climate, and the lengtl of our winter; but the same degree of latitude, gives in Europe a warmer climate than ours. If you take the latitude of Quebec on the north and Charleston on the south, and regarding these as lines of climate, extend them round the earth, you will enclose that portion of the globe on which nearly all high civilization of mankind has occurred. If Egypt and Arabia were for a time exceptions to this rule, we must remember that Cleopatra yielded to the Cæsars, and the crescent became fixed at Constantinople; and Egypt and Arabia have long been semi-barbarous countries.

In our climate, the earth yields us almost nothing without culture; yet is capable of yielding almost every thing we can desire. To the diligent and skilful cultivator, our soil yields a superfluous abundance. " $\mathrm{He}$ that tilleth his land, shall have plenty of bread; but he that will not plough by reason of the cold, shall beg in 
harvest, and shall have nothing." Poverty pursues the indolent, (even in summer,) with the constant step of a traveller; and in winter, it falls upon him like an armed man.

To enjoy life in our climate, we must be expensively housed, clothed, and fed; and a long winter must be provided for. But the labour to which we are impelled for the attainment of these things, is our great blessing. For the habit of industry leads us to develope the resources of the earth, to cultivate the arts which adorn society, ameliorate the sorrows of life, and subdue the ruggedness of the human heart. Habitual industry is the necessary instrument of a high civilization in a community of free men.

Did the soil yicld a spontaneous supply for our wants, as in the equatorial regions of the earth, it would be a sure source of degradation. Where the people can have "fullness of bread, with abundance of idleness," there will be found the vices of Sodom, and the dishonour of the human race. On the Gold Coast of Africa, the shade-tree is their house, and their chief toil is to gather perennial fruit. There, a man may be subsisted for six dollars a year; there, gold enough may be washed in an hour, to provide for the wants of a month; yet there, man is a poor, base barbarian - opposed to all improvement, and but little exalted above his rivals, the apes and monkeys. An English trader carried to the Gold Coast, a machine for washing gold with great facility, but he destroyed the machine to save his life from the violence of the people for whom he made it. There, the predominant notion of dignity is idleness.

An American gentleman asked a native king what was the African tradition of the origin of the different races 
of man. The king replied, "that at first God made all black men; but finding that the world would come to naught by reason of laziness, he afterward made some white men to drive the black men to work."

Now this tradition was doubtless invented to excuse slavery; but the facts of which it is made up, are not the less pertinent to illustrate our position.

On the coast of Brazil, where our citizens manufacture the Indian rubber, the natives and the Portuguese cannot be induced to labour beyond the poor supply of their daily wants; and hay is shipped to that coast from the port of New-York, to stuff the shoes, because the people will not cut the grass of Brazil and prepare it for the purpose.

The more carcfully we consider the influence of climate on the character and destiny of a people, the more shall we find cause to say "the lines are fallen to us in pleasant places." Our climate and our ancestry prepared the way for

The Institutions under Whicir We Live, AND to WHICI WE ARE DEEPLY INDEBTED.

Whoever has studied the Madison papers, - the Journal of the Convention, which formed the Federal Constitution, - will fecl the force of the last remark. He will acknowledge that the spirit of freedom in the people, seeking a protection for their industry, led the convention to form, and the States to adopt, the American constitution.

The soldiers and statesmen of that period, sought not for titles of nobility, or for any but a purchased and alienable right in the soil of our country. No grants were made of special privileges for any pursuit, except to those who gave to the public some equivalent. Ev- 
ery employment, and every place, was thrown open; and any man who pleased, might aspire to fortune, fame, or office. From that time onward there lias been a tendency in our country to enlarge, rather than to restrain, the application of the Democratic principle to our institutions of national and state government. Every man who has health may be a freeholder if he will. Every man may use his time, his talents, or his earnings, according to his own choice. The whole tendency of society is toward an equality of fortune. No wealth is hereditary. No fortune can remain long undivided. A fortune, independent or safe in the hands of an idle man, is a thing unknown. The wages of labour are high, and must be so just in proportion as the labourer has liberty and opportunity to set up for himself. Labour is the universal source of prosperity; all may have occasion to labour; and therefore every sort of honest industry is honourable. And hence it follows that all but shameless beggars, (a class not of native growth,) feel a powerful motive to attempt the improvement of their condition.

The liberty we enjoy is a priceless blessing. It consists not merely in the elective franchise, but also in our freedom from the trammels, which restrain the industry and enterprise of other and older nations. We have no remnants of feudal lordship. We have no nobility or throne to support. We choose the men who make our laws, and the magistrates who execute them; and if they disobey the will of the people, they are sure to be displaced. Our security in the enjoyment of life, liberty, and the pursuit of happiness, is so complete that we scarcely think of the possibility of a different state. And the whole working of our social system seems most perfectly adapted to illustrate the 
utmost extent to which the prosperity of a whole people is capable of being carried by themselves.

WE ARE ALSO FAVOURED BY OUR NEAT NEIGHBOURhood to the older aNd less FreE Nations of EUROPE.

It is true that our people have a natural and strong tendency to pursue what is immediately useful. We value science chiefly for its application to the arts of life. We study those things, which we can appropriate to increase our enjoyments, or our wealth. Our people are utilitarians, and not at all ashamed of the epithet. As a young people we are mostly occupied in planting and building; and so we must be occupied for a long time to come.

In this view of our character and condition, the foreign journals have tauntingly asked, "what has America ever done for mankind?" I answer: We have done what our mother country would not let us do without a family quarrel. We have made a country and a home for ourselves, and for the poor and oppressed of Europe. We have protected our industry by a prudent intercourse with other nations; we have covered our commerce with a flag, which the world has learned to respect; we have proved for fifty years, that we can do without the oppressive machinery of regal government and standing armies; we have done quite as much as our neighbours can have wished in the way of free govermment; and we have extended the blessings of a plain, but substantial education to the great mass of the population. But we have done more. All the honours of steam navigation and cotton culture are ours. Without arrogance therefore, we may say, we have bridged the ocean. We have appropriated the science, the arts, and the liter- 
ature of Europe, to the best uses of mankind. Within three weeks of its first appearance, every discovery in science, every invention of art, and every production of literature in Europe becomes our own. Da Guerre, in his fourteen years of experiments on light, and Herschell in his ceaseless observation of the Heavens, and Cuvier in his survey of all animal nature, laboured every hour for us. Our easy access to the ripe fruits of European science and letters, gives us amazing advantage in developing the resources, and perfecting the institutions of our own country, by the invention and application of machines in every department of industry. We acknowledge our obligation, but claim to have made large returns. The cotton gin alone has paid the debt.

These are some of the circumstantial advantages we enjoy for the working out of that problem of patriotism and philanthropy, the greatest good of the greatest number of the people.

For half a century we have been growing up in the use of these and other advantages. Could Franklin return and survey the face of his country, his largest hopes respecting the progress of that country would be exceeded. A walk through the printing-house of one of our daily papers would furnish him matter for days of delighted reflection. He would find with astonishment that a day-labourer cannot now afford to make a journey on foot. Could he visit your Fair and observe the wonderful results of those very lessons which his example and writings impressed on the character of his countrymen; could he see what ingenuity and industry liave accomplished - he would feel that he had not lived in vain. He would enjoy a higher satisfaction than when he concluded the treaty of peace with Great 
Britain, or when he saw the last name signed to the Federal Constitution.

To take even a passing notice of the various improvements of the present century in agriculture, commerce, and the mechanic arts, would require me to repeat some paragraph from almost every newspaper of forty years, along with the entire contents of some fifty periodical journals during the whole period of their publication. The records of these improvements would fill a library; and this library you have all been accustomed to read. But I propose to show,

Tilat while tuese improvements have meloraTED THE PIIYSICAI, CONDITION OF SOCIETY, THEY ALSO TEND TO ELEVATE THE INTELLECTUAL AND SOCIAL CHARACTER OF TIIE PEOPLE, AND ARE FAVOURABLE TO THEIR MORAL AND RELIGIOUS MPROVEMENT.

The physical condition of society, in our climate, is improved by every change which diminishes the labour and expense of cultivating, manufacturing, and exchanging the resources of the country. For experience proves, that where labour is reputable, the diminution of the amount required for any given result does not lead to indolence, but rather induces a man to enlarge his enterprise, by seeking to increase the number of his enjoyments. The amelioration takes place so gradually, that men in general scarcely observe how great it is, unless they compare the present time with their recollection of former years, or with the history of past ages.

Since the discovery and settlement of this island, the insurance between Hamburgh and Lisbon was more than fifty per cent. on the value of ship and cargo ; and now the insurance across the Atlantic is so small an item as to be scarcely regarded in estimating the profits 
of a voyage. And this great diminution results entirely from the improvements in ship-building and navigation. The improvements in the growing and manufacture of wool and cotton have reduced, by more than one-half, the entire expense of necessary clothing. These improvements are now increasing at a faster rate than at any former period. 'The " grain-reaper," which is now just entering the harvest field, will relieve the farmer at the most arduous and costly period of the year. The improvements in the consumption of fuel have produced a change equally great; and $I$ have no doubt, that still further changes for the better are to be made on this subject. The house, which fifteen years ago consumed two hundred and fifty dollars worth of fuel in a year, can now be better served for one hundred. And yet, more than half the fuel now consumed in this city, scrves only to warm the atmosphere above the tops of our houses.

I mention these few examples, but assure myself that very few in this asscmbly can need argument to prove how greatly the physical condition of all industrious people has been improved since the adoption of the Federal Constitution. And I pass to the

First topic of My SUBJECT, THAT THESE IMPROVEMENTS TEND TO ELEVATE TIIE INTELLECTUAL AND SOCIAL CIIARACTER OF THE PEOPLE.

This topic concerns us as patriots and lovers of our families; for the intellectual character of a people is one measure of their greatness; and their social character is the material of their happiness.

The intellectual character of a people is formed by the magnitude and number of the objects which engage their attention; and the facility they have for gaining 
a thorough knowledge of these objects. Now it is the tendency of all our improvements to take the hardest and most irksome part of our labour, and commit it to machines, which are moved by steam, or some other purely physical agent. Steam power blows the bellows, lifts the hammer, turns the lathe, and even guides the chisel of the worker in iron, brass, and silver. This gives the mechanic time to study the nature of metals, and the endless variety of uses to which they may be applied for the comfort or amusement of mankind. In this study he is led to some acquaintance with kindred arts. These arts lead him back to the principles of science involved in them; and make him a reader of the lives of the inventors of these arts, and of the history of the ages and countries in which they were invented and cherished. Hence, you may liear our blacksmith talk discreetly of the choice of ornaments, which may be taken from the details of Grecian or Gothic architecture to adorn that unsightly black hole in the parlor wall in which our fathers wasted their fuel, and which has now become a household ornament; while the economy of fuel enables us to pay for this ornament without encroaching on the claims of any comfort of life.

Steam power does the hardest drudgery of our builders. The sawing, and planing, and boring, and polishing, are transferred to machines; while the mechanic has time to study architecture in all its parts. And hence it has come to pass, that with the same labour and materials we get houses more commodious, better adapted for the economy of house-keeping, and also fitted to cultivate our taste for what is beautiful.

Some of us can remember the harsh sounds of the wool-cards and the flax-hatchel in the hands of our 
mothers. What filthy and painful toil was in almost every process of the handy-work of making our clothes. And now the drudgery is nearly all handed over to machines, while the intellectual part employs every branch of modern science and art. In a great cloth or print manufactory the whole circle of sciences taught in the University are brought into use. All that the University can teach, chemistry, mechanics, hydraulics, light, colours, and the arts of designing and engraving, are in constant requisition; and the success of the establishment depends on the skill with which these sciences and arts are applied to the growing fabrics. Distant countries are visited to bring home an improvement in a loom, a spindle, or a dye. The labourers in the factory have their ingenuity stimulated to the utmost to invent some improvement in their machines. And these employments are now occupying and animating some of the most acute and comprehensive minds in our country.

De Tocqueville has said, that "Agriculture is, perhaps, of all the useful arts, that which improves most. slowly among democratic nations. Frequently, indeed, it would seem to be stationary, because other arts are making rapid strides toward perfection. On the other hand, almost all the tastes and habits which the equality of conditions engenders, naturally lead men to commercial and industrial occupations."

Now there is some truth in this remark, as there is in many of this author's views, which a theory has led him to state too strongly. But suppose it to be true; yet, I think it can be shown, that the improvements of which we are discoursing have a powerful tendency to elevate the intellectual and social character of the ag- 
ricultural class of society in our country. And if it is true of this class, it must be true of all the others.

Increased facilities for commerce or manufactures turn indirectly to the advantage of the farmer and his family. But improvements in husbandry and domestic operations go directly to favour the better education of the farmers' sons and daughters. Every step gained in this direction draws out more candidates for the Academy, and rears the men who become distinguished in political, cominercial, and mechanical pursuits. The great men of our country come up habitually from the farming class. And the intellectual elevation of the youth of this class depends on the measure of time they can give to reading and study, and the access they have to books, maps, and scientific instruments.

On a furm of one to two hundred acres, a certain amount of labour must be done by the owner and his family, or they cannot meet the necessary expenses of a comfortable maintenance. The main chance must be minded by themselves. At certain periods of the year every boy that can spread hay, or carry a sheaf, or rake after a cart, must work. All the boys, who can hoe half a row, must work most of the summer. The work must be all done; and then the boys may go to school.

Whoever was a farmer's boy thirty years ago, sees now a vast change in favour of leisure for education, and the facilities for gaining knowledge. At that time, the hard, delving toil on the farm secmed to have no end. If there came a rainy day, there was no rest from toil; the clumsy tools of husbandry were to be mended or ground; the threshing flail, and hand-fan were to be swung, till our eyes were filled with dust, and our hands ready to drop; the younger boys were shelling corn on 
the handle of a frying-pan; and the youngest of all was turning the quill-wheel, or picking wool, or tugging at the churn-handle. At the approach of winter we hoped to get to school; but the hope was long deferred. The fair days were required to cut and bring home vast quantities of fuel; and a boy could drive the team. And when this was done, then came the horrid work of dressing flax. Many boys have a dreary remembrance of that vile employment; and would have kissed the hand of the man who would have ground up the last flaxseed on the earth.

But now, every one of these labours has been turned over to machines, which have reduced the work of months to a few days. Flax is scarcely cultivated. A few cords of wood supply the farm-house. The tools of husbandry have been perfected. Half the labour of the farm is superseded; and three-fourths of that which used to be laid on the boys, is no longer required. Horticulture has found favour with the farmers. Fruit trees and flowers surround almost every rural dwelling. The rearing of fine domestic animals, occupies general attention. The intellectual part of agriculture has in. creased, just in proportion as toil has been diminished. The farmer is becoming a botanist, a geologist, a chemist. He reads; he corresponds with ingenious men; he communicates his experience through the public journals; he finds time for occasional journies ; his manners are improved; his taste is refined; his intellect is elevated; and his social character is improved.

But there has been a still greater improvement in the facilities for the attainment of knowledge among the children and youth of rural districts in our country.

The district school library now furnished by the Harpers for $\$ 20$, is worth more for the education of a 
family, than all the books which could be found in some towns of this state thirty years ago.

We then lacked the necessary means for forming a taste for intellectual improvement. The boy who learned Pike's arithmetic was a distinguished boy; and Flint's surveying, made him a sure candidate for greatness. Our diversions were gross, expensive, and dangerous; and youthful indiscretion frequently brought whole families to open shame. But the social state has been improved almost as much as the physical condition of the people; and this happy change is the result of labour-saving machines.

But this topic is not half exhausted; for if the change wrought in favour of the education of boys has been great, the change in favour of female education and refinement has been greater. The drudgery of the farmer's wife and daughters, has been almost annihilated by the cotton and woollen factories, and the improved instruments of household labour. 'There has been some alarm among men on this subject; but there is nothing to fear. The thrifty farmer can well afford the luxury of seeing his wife and daughters in their improved condition. Even if he labours an extra hour for their sake, he will be all the happier for the sacrifice.

If his household affairs are prudently managed, the products of his farm will not be lialf consumed in providing for the bare necessities of his family. When these are secured, all the best ends of human life will be favoured, by meliorating the condition, promoting the intellectual culture, and refining the manners and tastes of his wife and daughters. No other expenditure is so sure to bring home a large return of virtue, dignity, and fair renown. For woman is the guardian angel of the social state; the presiding goddess of domestic happiness. 
She must be refined, or man cannot be civilized; to facilitate her refinement, is not to make her vain or indolent. Emancipated from her low drudgery, she turns her hand to more delicate, but not less useful employments; such employments are multiplying in number and value with every day's improvements. Articles of daily consumption and vast amount, now procured from Europe, are beginning to be manufactured by the women and children of our country. Our straw goods are taking the place of the English and Italian. And, passing over other objects, we may hereafter expect an extensive application of female industry to the culture of silk.

When the fever of speculation has gone by, and the laughers at speculation have had their turn, the mulberry trees will be found growing in vast numbers all over the face of this country. And when there has been time to mature their growth, the business will be found attractive and profitable. The end of this speculation will resemble that of the speculation in merino sheep. The fever had its course, and the laughers their fun; but the improved breed of sheep remains, the public revenue from imported fine wool and cloth has been reduced, and a rich blessing to our country has been the result.

To a large and still growing extent, the instruction of children is now committed to the gentler sex. And they are doing the work with commendable zeal and success.

And even those young women, who used to go out as spinsters, are now able to provide for themselves in a better way by working in the factories. I am well informed of the state and results of this sort of employment in New-England; and have no doubt, that the results are friendly to the cause of intelligence and good manners. 
It is a known fact, that within thirty years, the measure of time appropriated to the education of children, in the same district has been more than doubled. The advantages arising from better books, maps, globes, and other apparatus, liave been augmented in an equal degree. And, while the whole community is better housed, fed, and clothed than before, can it be questioned, that the intellectual and social character of the people has been elevated?

Turn your thoughts to the true history of this matter. The mind is cultivated by its linowledge of the qualities of things, and of the relations which subsist between those things. To trace things back to their elements, to observe their combinations, mark the changes through which they pass, and discover the laws to which they conform - this is the very work of philosophy, the daily business of pure science, as a method of discovery. 'To apply these results of observation and discovery to the uses of mankind, in all the ways by which labour can be saved and enjoyment increased - this is the business of practical science: and the results so applied are but other names for all the useful arts of life. 'Thus you see, how closely the inventor in arts is allied to the discoverer in pure science. And can you suppose, that the mass of the people can be daily employed in the use of these inventions, without themselves secking to investigate the causes or laws from which they spring? Is there not in common minds a natural proneness to such inquiries, whenever the door to them is opened? Is there not an intellectual pleasure in such inquiries, which both animates and rewards the search? Yes, and the leisure, which prosperity brings in its train is improved by great numbers of our youth, who love science for her own intrinsic beauty, and forego many grat- 
ifications, that they may learn and reveal yet more of the secrets of nature. In their intercourse with society they diffuse the same spirit; they impart an intellectual tone and taste to the rising generation; and they enlighten the ingenuity of those, who give themselves to the more strictly practical pursuits of invention.

I grant, that pure science and good letters are cultivated by the favoured few, in foreign universities and under royal patronage, beyond what is done in our new and republican country. But is it not a higher glory to have raised the great mass of the people to a degree of intelligence, which. softens their manners, cheers their social life, and unfits them for being the mere tools of tyrants and food for cannon?

The course of discovery and invention in physical science has astonished the civilized world during the last forty years. Triumphs already gained gire intimation of still greater to be expected. And I live in no fear that civilized man will ever recede from the ground he has already gained. Science is no longer shut up in the cloisters of the few. Philosophers no longer, like Archimedes, despise the applications of science to practical purposes. The art of printing has rendered the best books on all subjects of learning the most common books. The learning of the world is spread over the world. The causes, which once overwhelmed the science of civilized man, cannot operate again in any free country; and the growth of civil liberty is as certain as the course of time. The wars which have desolated the earth are not again to rage with the same ease and for the same causes. The melioration of the physical condition of the people must ever render it more costly and more difficult to raise and support great armies. The temperance reform in Ireland has already 
cmptied the criminal courts, and jails, and gin-shops, the three best places for the enlistment of soldiers. And if Ireland is true to herself in the course she has commenced for the education of the common people, her redemption is sure.

Strange as it may seem, there are some men, who fear that labour-saving machines will deprive the poor of their livelihood. A gentleman of fortune and leisure, standing with me at the fair, over a new machine of this sort, observed, that "very soon the poor people, who arrive in our country will have nothing to do." Formerly this apprehension was a serious obstacle to improvements in the arts of life. When the lathe for turning gun-stocks was invented, years passed away before any manufacturer was found who dared to introduce it. And I well remember that when Lemuel Pomeroy of Pittsfield, the real benefactor of that town, made the experiment, he was deemed a crucl enemy of a labouring class of men.

But what is the practical effect of all such changes? There may be some temporary inconvenience for those who have to change their hard toil for a more cleanly and intellectual occupation. The new occupation must be sought and learned; but the lasting benefit to all parties cannot be doubted. When Richard Hoe invented a mode of attaching the handle of the bellows to the engine, which lifts the hammer at each anvil in his vast machine-shop, he dispensed with the service of eiglit boys. But the boys are transferred to higher employments, and their destiny in life is changed. The hands dismissed from the press by the invention of Napier, and the use of steam power, became type-setters, proofreaders, clerks, editors of newspapers, and authors. In short, all the hands released from drudgery by the use 
of 'machines, if they are not called for in the higher departments of mechanical, or commercial labour, may find an unfailing resource in the pursuits of agriculture. There lies the strength of the people. And there may ever be found a sure reward of industry, and the means of gradually raising one's condition in life.

I have said that "the labouring class are the true conservators of society." Beside these there is a limited class, who are above the immediate necessity to labour, and there is a numerous class, who are below the motives and opportunities for profitable labour. To bring this upper class into co-operation with those who labour, and to lift up this lower class to an honest independence, and to cultivate the intellectual and social character of the whole, is the aim of the American Institute. This aim is in harmony with our civil institutions. It is worthy of philanthropists. It co-operates with the providence and the word of that Father of us all, "who maketh his sun to rise on the evil and on the good, and sendeth rain on the just and on the unjust." Therefore, by an easy transition, we pass to the other part of our subject.

That these improvements in agriculture, manufactures, and commerce, are favourable to THE MoraL AND RELIGIOUS IMPROVEMENT OF THE PEOPLE.

The history of nations, but especially of free nations, tells us that all the interests of society must suffer, where morals are corrupted and religion is dishonoured. It would ill become us to rejoice in any prosperity which is unfriendly to these vital interests of mankind. The shades of our ancestors would rebuke us; and the curse of posterity would fall on our graves. And I approach this topic, aware of the responsibility it involves.

Immorality and impiety may attach themselves to a 4 
very high or to a very low state of civilization. No reliance is to be placed, for moral and religious ends, on any, but the obvious and appropriate means. And all I propose to show, is, that the improvements, which we are considering, are friendly to the moral and religious improvement of the people.

That the manners of society are cherished, purified, and elevated by these improvements, will scarcely be questioned. Where all things tend toward an equality of condition, and no class is independent of other classes, we are in little danger from that false refinement of manners, which appears in aristocratic countries. All that we gain in manners is substantial gain. And whatever cultivates a taste for the beautiful, or softens the social affections, or increases the facilities for generous actions, or brings us to the knowledge of good letters, goes directly to the account of good manners.

But the manners of society are intimately allied to its morals. "Vice," said Sir Edmund Burke, "loses half its evil by losing all its grossness." Good manners are a discipline of the understanding and the heart ; and they restrain unnumbered acts and tendencies of immorality, which would prevail in a lower state of civilization. The equality of condition among our citizens, subjects every man to the observation, and every vicious man to he animadversion, of his neighbours; and thus the state of our manners operates as a powerful restraint on immorality. No man among us, except in the solitude of a great city, can openly violate the decorums of life, and avoid feeling the indignation of society. In the judgement of enlightened foreigners, our institutions and our condition are highly favourable to good morals.

The opportunity which every man enjoys to improve his condition, naturally disposes him to be a moral man. 
The labourer, who has laid up the wages of a single month, has something at stake on the institutions of the country. He begins to value his citizenship, and takes an interest in the public welfare. His self-respect grows with all his savings. Self-respect induces a respect for the opinions of other men. And he who at first assumes a virtue for the sake of appearances to others, may learn to practise that virtue for the satisfaction it yields. And I think it will be found, that where the physical condition of society has been most improved, and its intellectual character most advanced, there the morals of the people have been cherished. But show me the little village where they are content with a low condition, where they neglect the improved methods of labour, and where they prefer idleness to prosperity; and there it will be found, that they prefer the grog-shop to the schoolhouse, and the justices court to the sanctuary.

But the morality of a people has an intimate connection with their respect for pure religion. 'The morality of a people will never be more exalted than their religious opinions and sentiments ; and religion and morality are favoured by whatever favours intellectual elevation.

It is a remarkable fact, that nearly all the nations on earth, who worship the one living and true God, are men of the Caucassian race, the race as much distinguished from all others by intellectual superiority and practical wisdom, as by the developement of their brain and the colour of their skin. And this race inhabit chiefly within the latitudes of Quebec and New-Orleans on both sides of the globe.

In all true science, that is, in all true knowledge of the nature of things, their qualities, their changes, and their relations, we approximate toward the Maker of all things. It is the wisdom of a man to search out a mat- 
ter. When Barrow was asked why he left the pulpit or the chair of mathematics in the University, he answered, "God is a geometer."

Imperfections and mistakes in physical science have been a fruitful source of popular infidelity. The whole skeptical system of Monboddo was founded on the supposition that man, by a series of fortunate changes has gradually risen from the race of brute animals; a supposition which Cuvier has demonstrated to be erroneous. For that greatest of comparative anatomists has proved beyond a doubt, that no living thing on earth ever passes from one distinct class to another; but each continues after its own kind.

The discoveries and observations in physical science have exploded numerous forms of popular infidelity. Physical science has, in modern times, been successfully applied to illustrate the being and attributes of the Deity. Tucker, in his "light of nature," laid the foundation on which Paley and Chalmers have built up the still growing science of natural theology. And when the whole system of nature shall be searched out, and physical science rendered complete, the harmony of natural and revealed religion will be cstablished; and infidelity will find no resting place but in the closets of the doubting metaphysicians. There it will be nearly harmless, because the common people will never understand its language.

While, therefore, the secrets of science are laid open to the farmer, the mechanic, and the merchant, in the improvements we enjoy, truth has a more easy access to the mind, and the truth of religion comes home to the business and the bosoms of men, as being a practical good, profitable for the life that now is, as well as for that which is to come. I have yet to learn, that prosperity depending on regular and enlightened industry, 
is in any way unfriendly to the sentiments or the belief of religion.

The discussion of this topic cannot now be prolonged. But I love to consult the auspices of our country, and collect the indications of her future career. I love to forecast the stability of her institutions, the mignitude of her resources, and the growing happiness of her swelling population. I love to rekindle in my own breast, the sacred fire of patriotism, and cherish its glowing anticipations. I love to dispel those fears, which accidental causes have awakened in minds, prone to extremes, and discouraged by passing misfortunes. Are you not weary of the croakings suggested by fluctuations in commerce, which were brought on by the excesses of paper money, and of foreign importations? Is the republic therefore to be despaired of? Trade and commerce will ever be liable to fluctuations; but each successive wave will be smaller than the last. When a bubble of illegitimate trade has been inflated beyond its capacity and bursts, the mischief is great, but temporary : business gradualiy revives, but revives in new forms, under smaller profits, and closer competition; requiring increased caution, sagacity and industry ; and, to a large extent, it revives in new hands. The unfortunate look for its return in the old channels, and they often look in vain. But nature, constant to her own laws, suffers no fluctuations. Seed-time and harvest return in their due course. The earth teems with abundance. Greater numbers apply themselves to agriculture. Richer harvests wave over the fields. The productions of the earth call forth again the enterprise of the mechanic, and reward his labours. The growing wealth of the country calls again for the labours of the merchant; and again his prudent and sagacious in- 
dustry gives him a moderate and safe accumulation of wealth.

These revolutions in business are incidental to our country. They result from the proudest features of our institutions, and our character - from our freedom in action, our vigour in enterprise, and our easy confidence in each other. They are the excessive pulsations of a growing and youthful body; and they give promise of a gigantic maturity. Experience will render them less frequent, and less injurious while they last; but all that is valuable in the highest idea of home and of country will be left. Each new convulsion will teach us new lessons of political economy; will throw us back on the sources of wealth within our own country; and will teach us to cultivate the soil more perfectly, and to bring into use the geological and mineral resources of our own mountains and vallies.

These pursuits will employ the science of the learned, the skill of the ingenious, the labour of the diligent, and the capital of the enterprising. These must ever be the sources of our national wealth. The products of these pursuits must determine the measure of our commerce; for our surplus production is all we can give in exchange for the productions of other countries. A wise regard to these pursuits must indicate the true course of our government for the protection and encouragem nnt of American ingenuity and industry. And it will be glory enough for any people to preserve the institutions of our fathers, to develope the resources of our country, and to render it what it is destined to become, unless our want of virtue and patriotism shall prevent.

W inen I reflect on the probable destiny of our country, my imagination can scarcely grasp the results of 
sober calculation. Our territory extends across the continent, and through every degree of latitude adapted to a high civilization. Our soil is adapted to every production except a few articles of luxury and ornament; and is capable of supporting a population greater than all Europe. We have iron, copper, lead, coal, marble, and granite, sufficient for the world, and easy of access. These sources of wealth are coming to light along with the improvements in their adaptation to the use of man. Every successive Fair of the American Institute exhibits a new collection of labour-saving machines, to which coal and iron can apply the power of steam, and make them our untiring, undying servants.

These servants are cheaply fed, and wear no clothing; they have no period of infancy, or old age, to be provided for; they raise no mutinies; and they obey without the lash. We have not yet learned how many of these servants may be directed by one skilful hand. But allowing the progress of improvement to continue what it has been, during the last forty years, it is quite safe to predict, that before the population of this country shall reach fifty millions, the machinery of the country will be equal to the labour of five hundred millions. In other words, the productive industry of the country will be equal to the undivided labour of a population ten times as great as that to be provided for. The men are now living, who will see these grand results. The children are born, who will see the double of these results. And how will this vast accumulation of wealth be applied?

This is a question of vital interest. But the nature of the case suggests the answer which philanthropy desires to hear.

The intellectual and moral character of the people 
is to be sustained and advanced. The accumulation of wealth is to be made by the people, and remain in their hands. It will not be collected by hundreds of slaves for the luxury and pride of one master ; nor by hundreds of serfs for one lord; nor by thousands of subjects, to be lavished on the pomps and vices of royalty; but the common wealth will be advanced. The industrious and virtuous of the people at large, will be better housed, better clothed, better fed, and better learned. The log cabin will give way to the tasteful and commodious dwelling. The deep forest will become a fruitful field. The desert will blossom as the rose. And I doubt not that humanity will be cherished, while learning and religion will be patronized.

I am aware that on these points, there are many fears indulged concerning the future growth of our country. De Tocqueville has suggested the fear that manufactures may become concentrated in a few hands, and thus lead to a new form of aristocracy, which will oppress the labouring class by reducing wages, and preventing edıcation. But he takes no notice of the fact, that so long as good lands are cheap, and cultivation easy, honourable, and profitable, it will not be possible to command the labour of men at low prices. Nor has it yet appeared, that great manufactories have a tendency to restrain education. The schools at Lowell, and in the other great manufacturing districts of New-England, are of a higher order than the common schools of the rural districts; and these schools are more uniformly attended than the common schools. Experience has proved that it is cheaper to have schools and churches, than to live without them. In the manufactories of Rhode-Island, there is certainly a higher state of education, than among the farmers of the same state. The proprietors 
of these great establishments, to my knowledge, are the careful patrons of education and morals. They act on the principle, that it costs less to prevent vice, than to restrain it. The white steeple of the church, is the first object that meets the eye of the traveller in his approach to a manufacturing village. To me, it seems obvious, that the danger apprehended cannot come upon us, until the constitution is abolished, and the foundations of democracy are broken up.

But will not religion, science, literature, and the fine arts, languish for want of patronage and support? This result is feared, and the fear is often expressed. An anxious concern on this subject is felt in our behalf on the other side of the ocean, especially by the church and state party in Great Britain. But what is the ground of this fear? I have listened to all its suggestions and ill-bodings, and they may all be resolved into one short sentence-the people cannot be trusted. Well, if this is true, then the republic is to be despaired of ; and our experiment of a free government, is to be a failure. But this is a denial of the very first article in our political creed. And who of us is prepared to make this denial? If any, let him renounce his birth-right; and let him retire and pray to Jupiter to send us down some $\log$ from the tree of legitimate sovereignty. True republicans are not prepared for this denial. The people can be trusted with the elective franchise; they can be trusted for the support of religion, and the encouragement of science, letters, and the arts.

The founders of our government made a novel experiment, when they left out of their plan any provision for the establishment and support of religion. They left this matter to the choice of the people. Thus far, our experience commends the wisdom of the plan : the 
people can be trusted; religion has gained power by gaining her liberty.

Religion must be perfectly spontaneous, or it is not worthy of the name. Religion is not the production of priests, or philosophers, or rulers; but pure religion produced both the priest, and the worshipper, by commending its own truth and goodness to the conscience of both. And it depends for its support on the conscience of civilized, enlightened man : there, it can trust securely; and if it could not, I should be almost persuaded to be an infidel. The history and the present state of our country give clear proof that the people of these United States are, and will be, the supporters of religion. I venture to assert, that according to our numbers, and our wcalth, the people of the northern and middle states have expended more money on religious institutions in the last fifty years, than any other people on the globe.

And now in regard to the patronage of science, letters, and arts. Cannot the people understand the value of these things? Are they not daily tracing the improvements of the plough, the saw, the mill, the lathe, the steam-engine, and all their labour-saving machines, back to the principles of pure science? Are they not pleased with the grand and the bcautiful in art? Are not more copies of the best literature of England sold in America than in old England herself?

The prospering class of men are ever disposed to be bountiful toward science and art. This truth is a proverb in all the world; but it applies with double force in a country where there is no hereditary wealth; where there is no place or use for princely fortunes, and where no man can find distinction so surely as by patronising the institutions of learning.

The patronage of kings and nobles bestows on sci- 
ence and art only a small part of what has first been taken from the people, while the people have no share in the honour. With us, the people who give, consider the institutions of science and art as their own. And this feeling of ownership, in the minds of the people, gives a sure pledge, that their own will not languish or be despised.

When Stephen Girard looked around him for a monument, he chose not the stately column, nor the tomb of Mausolus; but he founded and endowed a college, where his memory will be forever cherished in the hearts of orphans, and of dying widows, who leave their sons behind them. May we not look for similar benefactors among the men who are now making overgrown fortunes in our country?

But we are not left to conjecture as to what will be done for science, art, and letters, by the citizens of this republic. They have been acting on this subject, and acting with zeal and munificence.

Let those who consider us wanting in this matter, remember that we are laying new foundations; that we are building for posterity. Where a few years ago stood a forest or a sandbank, are now reared the lofty walls of Academies, Lyceums, Colleges, Libraries, and Universities. These buildings are alike ornamental as specimens of architecture, and honourable to the forecast of their bold projectors. They indicate that we expect to be a great, and prosperous, and happy people.

The Institution to which I am attached, has sprung up within a few years, at an expense of a quarter of a million; and solely from the munificence of the citizens of New-York. I see in this audience, the men, who have given tens of thousands to this enterprise. And I verily believe, that the people of the United States have, 
within thirty years past, appropriated more of their wealth to the cause of science, arts, and letters, than any other people of the same numbers and wealth, on the face of the earth.

We have our full share of students and travellers abroad in the old world, collecting and bringing home whatever can enlarge or invigorate our course of learning, or add to the ornament of life. But these things must come gradually, and they must ever be subordinate to the common interests and enjoyments of the people at large. We admire the arts of Europe; we reverence the antiquities of Italy, Greece, and Egypt; but, at the price those arts and antiquities have cost, we desire them not. Freemen cannot afford to build pyramids, or temples, or monuments to the vanity of one man. If we imitate their architecture, it must be in buildings for public use. And that we can imitate it for this purpose, let the Custom-House, the Exchange, and the University be witnesses.

But I trespass on your time, and dwell too long in repelling the fears which some entertain concerning the grand and glorious tendency of our country.

I return to a rapid review of the train of thought we have pursued.

If these improvements in agriculture, commerce, and the mechanical arts are meliorating the physical condition of the people, elevating their intellectual and social character, and favouring their moral and religious cul. ture, - then, the inventors of machines and the improvers of the arts of life, may rejoice, that they are chief contributors to these results. Inventors are rarely stimulated by mercenary hopes; they are rarely rewarded. I class them with statesmen, profound judges, great philosophers, and deep moralists, who live for mankind, 
and expect their reward from future ages and other countries as well as their own. Their names will be recorded with those of Bacon, and Burke, and Hale, and Davy, and Bishop Butler. They will be more revered as man becomes more civilized. And ere long, their numbers and their deeds will claim for them a separate scroll, on which the American column, with Franklin at its head, will be long and full. With the single names of Fulton, and Whitney, and Evans, on our banner, we will not blush to face the world, and claim our place among those who have meliorated the condition of mankind.

Next to inventors, those who patronise and co-operate with them may exult in the fruits of their labour. Livingston will be longest remembered as the friend of Fulton; and justly so : for it requires something of the sagacity of genius itself to forcsee and encourage the triumph of genius. But the associated patronage of ingenious arts and labours is godlike action. It works on the character and condition of society like the hand of nature, which paints at the same moment on every flower of every field, and silently diffuses fragrance and beauty and fruitfulness over all the earth. My theme compels my eulogy to pause on the name of the American Institute. The name is indicative of its character ; and its influence is coextensive with its name.

Kindred to the leading thought of this hour, and resulting from it, is the hope, that human degradation, want, and suffering, will be gradually diminished. The road to the improvement of our condition is open to all sorts of men, and the access to it is easy. Machinery is gradually diminishing the use of human hands for degrading labour. The steam-engine is already super- 
seding the sailor, the marine, the hod-lifter, and a thousand other drudges.

If there was a shadow of truth in that paradox of a profound southern statcsman, that slavery is needful in a country of freemen, that shadow must fly away before the drudging power of steam and machinery.

Already the New-England farmer and mechanic have their millions of iron horses and iron slaves. These can be multiplied without limit. And they are less costly, and more ingenious, and more to be trusted than sinews bought and sold. I speak not in reproach or exultation; but I would, if possible, call forth the genius and industry of the south, to the developement of resources which might make Virginia again what she was in the days of Washington and Madison, the key-stone, if not the empire state.

The hours of this festival will soon be past. Its influence will flow out to the borders of the land. May each succeeding year witness the enlargement and the growing influence of the fair of the American Institute on the minds and the fortunes of all classes in society. 



LIBRARY OF CONGRESS ||||||||||||||||||||||||||||||||||||||||||

\section{PRINTING.}

The subscrbers have removed chici PRINTING ESTABLISHMENT from ONo. 2 Elonn-street to ONo. 111 FULTON-STREET, Getween Nassour and Mbilliasn. HGaving an extensive assoutment of the MOST IMPROVED MODERN MATERIALS, they are prepared to fulfit all orders in their line with puncluality and clegance. They will cxccule in the best manner, works on

$$
\begin{aligned}
& \text { Elbathematics, Eblgebra, } \\
& \text { Elbedicine, Divinity, } \\
& \text { Couv, with blank forms of every description; } \\
& \text { Circulars for professional gentlemen, mer- } \\
& \text { chants, and others; } \\
& \text { The various forms used in Banks and } \\
& \text { Insurance Companies; } \\
& \text { PS amplilets, Cards, Showbills, 8jc. Yjc. }
\end{aligned}
$$

Their charges shall be at the most moderate rates, that the nature of the busincss will auchoreze, for cash prayments.

HOPKINS \& JENNINGS.

July, 1840. 